\title{
PROGEEDINGS
}

\author{
OF THE \\ American Society of International LaW \\ AT ITS
}

\section{SIXTH ANNUAL MEETING}

HELD AT

WASHINGTON, D. C.

APRIL 25-27, 1912

BYRON S. ADAMS, PRINTER

Washington, D. C.

1912 
CoPyright, 1912, BY

THE AMERICAN SOCIETY OF INTERNATIONAL LAW. 


\section{TABLE OF CONTENTS.}

OFFICERS FOR THE YEAR $1912-1913 \ldots \ldots \ldots \ldots \ldots \ldots \ldots \ldots \ldots \ldots \ldots \ldots . \ldots \ldots$

Constitution of the American Soctety of International Law.......... VII

Report of the Sixth .Annual Meeting $\ldots \ldots \ldots \ldots \ldots \ldots \ldots \ldots \ldots, 1$

\section{FIRST Session}

Thursday, April 25, I9I2, at 8 o'clock p. $m$.

Opening remarks of the President of the Society $\ldots \ldots \ldots \ldots \ldots \ldots \ldots, 1$

The real significance of the Declaration of London. Hon. Elihu Root...... 4

Some considerations on the past, present and future of international law.

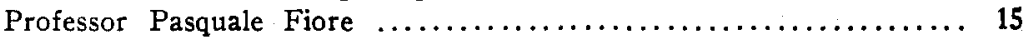

The international regulation of ocean travel. Hon. Everett $P$. Wheeler.. 36

\section{Second Session}

Friday, April 26, I9I2, at 1o o'clock a. $m$.

Humanitarian diplomacy of the United States. Hon. Oscar S. Straus..... 45

Remarks: Mr. Everett P. Wheeler ........................... 54

Professor Theodore P. Ion ........................5, 56

Mr. Christian L. Lange ........................... 55

Mr. Theodore Marburg ............................. 56

Mr. Joseph Wheless ............................... 57

Revision of arbitral awards. Hon. Joaquin D. Casasus................. 59

Remarks: Mr. Frederic D. McKenney ......................... 63

The Monroe Doctrine and International Law. Hon. Luis Anderson..... 72

Manting of the Executive Council, Friday, April 26, 19i2, 2:30 o'clock

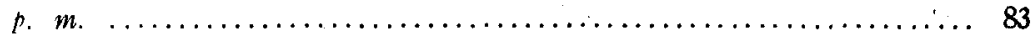

THIRD SEŚSION

Friday, April 26, I9I2, at 8 o'clock p. $m$.

The question of the general arbitration treaties. Hon. George Turner... . 87

General arbitration treaties. Hon. Richard Olney................. 102

Remarks: Mr. Jackson H. Ralston ............................. 106

Mr. W. C. Dennis .............................. 112

The codification of the laws of naval warfare. Rear Admiral Charles

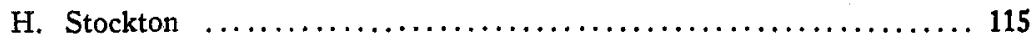

The effects of war upon international conventions and upon private con-

tracts. Major-General George B: Davis..................... 124 
The Marine belt and the question of territorial waters. Mr. Thomas

Willing Balch $\ldots \ldots \ldots \ldots \ldots \ldots \ldots \ldots \ldots \ldots \ldots \ldots \ldots \ldots \ldots \ldots \ldots, 132$

Remarks: Mr. Edwin M. Borchard ............................. 139

\section{Fourth Sesston}

Saturday, April 27, 1912, at 10 o'clock a. m.

A permanent court of international justice. Mr. James L. Tryon....... 144 The need of revision of procedure before international courts of arbitration.

Mr. Robert Lansing ................................... 158

Remarks: Dr. Benjamin F. Trueblood ....................... 167

A permanent court of international justice. Hon. Everett P. Wheeler.... 171

Remarks: Mr. Christian L. Lange ......................... 176

The organization and procedure of the Third Hague Conference. Hon.

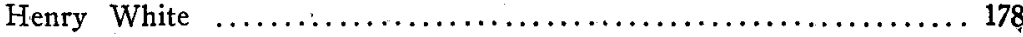

Remarks: Mr. W. M. Collier ................................. 187

Professor Theodore P. Ion............................. 188

Mr. Denys P. Myers .............................. 188

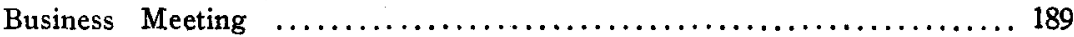

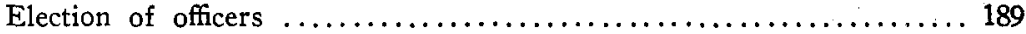

Selection of honorary member $\ldots \ldots \ldots \ldots \ldots \ldots \ldots \ldots \ldots \ldots . \ldots 190$

Resolution concerning international conference on regulation of ocean traffic . . ........................................ 191

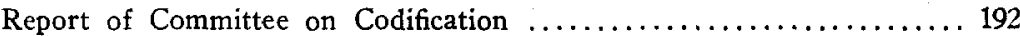

Meeting of the Executive Counciz, Saturday, April 27, 19I2, 4:20 o'clock

p. m. .................................................. 194

\section{Annual Banquet}

Remarks of Mr. Frederic R. Coudert, Toastmaster..197, 206, 213, 219, 226, 229

Responses:

Hon. Henry Cabot Lodge ................................. 200

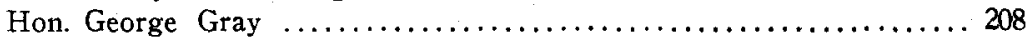

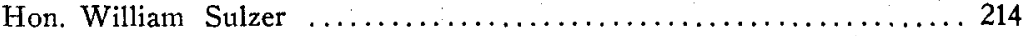

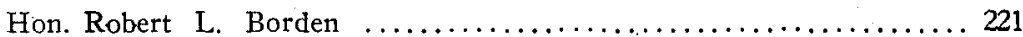

Mr. Christian L. Lange ............................ 227

REPORTS OF THE TREASURER :

1911 . . ............................................. 230

$1912 \ldots \ldots \ldots \ldots \ldots \ldots \ldots \ldots \ldots \ldots \ldots \ldots \ldots \ldots \ldots \ldots \ldots \ldots \ldots \ldots \ldots \ldots \ldots \ldots \ldots \ldots \ldots \ldots, 233$

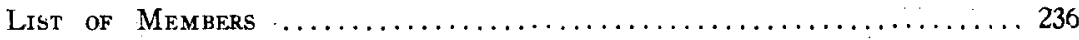

